\title{
Kelekatan Modal Sosial Pada Keluarga Santri Di Pulau Madura
}

\author{
${ }^{1}$ Farahdilla Kutsiyah, ${ }^{2}$ Lukmanul Hakim, ${ }^{3}$ Ummu Kulsum \\ 1,2 Institut Agama Islam Negeri Madura, ${ }^{3}$ Universitas Islam Madura \\ Jalan Panglegur Km 4 Pamekasan, Madura \\ E-mail: keindahanmaduraku@gmail.com
}

\begin{abstract}
A large capital owned by Pesantren (Islamic boarding schools) is the Ahlus sunnah waljamaah values which are juxtaposed with local wisdom. Madura Island is known as the island of a thousand Pesantren. Its existence affects the social structure and interaction of people on the island of Madura, where the resources embedded on them are called social capital. This study uses the librarian research and personal observation at several location points in Madura Island. The results showed that the attachment of Pesantren's social capital on santri families in Madura Island was the norm namely obedience to Kiai (religious leaders of Islamic boarding schools), barokah (divine blessing), high solidarity among fellow santri and simplicity. Networks such as recitation (koloman), alumnus ties, Istighozah (praying together for proposing forgiveness and hope), togetherness "ala pondok pesantren" (pesantren style)" and Imtihan (contest at the end of an academic year). Trust is honest and convinced behaviour as well as a belief of santri families towards pesantren.
\end{abstract}

Keywords: Madura Island; Pesantren; Santri families; social capital.

\begin{abstract}
Abstrak
Modal besar yang dimiliki pesantren adalah nilai-nilai Ahlus sunnah waljamaah (Aswaja) yang disandingkan dengan kearifan lokal. Pulau Madura dikenal sebagai Pulau seribu pesantren. Keberadaannya berdampak terhadap struktur dan interaksi sosial masyarakat di Pulau Madura, dimana didalamnya terlekat modal sosial. Penelitian ini menggunakan penelusuran kepustakaan dan observasi personal pada beberapa titik lokasi di Pulau Madura. Hasil penelitian menunjukkan bahwa kelekatan modal sosial pesantren pada keluarga santri di Pulau Madura adalah norma yakni kepatuhan terhadap Kiai, barokah, solidaritas tinggi antar sesama santri dan kesederhanaan, Jaringan seperti pengajian (koloman), ikatan alumni, Istighozah, kebersamaan "ala pondok" dan Imtihan, kepercayaan yakni perilaku jujur \& amanah serta kepercayaan keluarga santri terhadap pesantren.
\end{abstract}

Kata Kunci: Modal sosial; Keluarga Santri; Pesantren; Pulau Madura.

\section{Pendahuluan}

Modal besar yang dimiliki pesantren adalah nilai-nilai Ahlus sunnah waljamaah (Aswaja) yang disandingkan dengan kearifan lokal. Nilai-nilai ini ekuivalen dengan makna keislaman, dan keindonesiaan. Dengan kata, pesantren berkembang dari pengalaman sosiologis masyarakat dan juga 
mempunyai keterkaitan erat dengan komunitas lingkungannya. Sifat kompromistis dan kelenturan pesantren dengan ajaran aswaja-nya merupakan salah satu faktor utama pesantren bisa eksis hingga saat ini. ${ }^{1}$

Ajaran Ahlus sunnah waljamaah dengan beberapa prinsip dasar seperti tasamuh, tawazun, ta'adul (i'tidal), tawasuth dan tasyawur (musyawarah) sesuai dasar dengan Al Qur'an. ${ }^{2}$ Tawasuth (moderat) adalah sikap wajar, toleran, mau mengerti pendirian sendiri, baik sebagai kelompok maupun sebagai pribadi. Tasamuh (toleransi) hakikatnya adalah sebuah sikap keberagamaan dan kemasyarakatan yang menerima kehidupan sebagai sesuatu yang beragam. Tawazun (seimbang atau proporsional). I'tidal adalah terus menerus berlaku adil, sikap tegak lurus di segala hal. ${ }^{3}$ Ini berarti ahlusunnah wal jamaah memilih jalan tengah atau moderat, tetap memilih berada di tengah untuk menangani konflik, baik itu keagamaan, politik dan sosial.

Kearifan lokal seperti budaya yang bercorak Hindu, Budha maupun kepercayaan tradisi lainnya diapresiasi oleh para penyebar Islam (walisanga) dan kemudian diintegrasikan kedalam doktrin dan budaya Islam. Pertimbangan yang dilakukan mereka yakni untuk membangun sebuah sistem pesantren adalah karena Indonesia saat penyebaran Islam berlangsung masih didominasi ajaran Hindu-Budha. Sebab itulah pilihan pesantren sebagai model lembaga dakwah adalah sebagai bentuk akulturasi dan kontak budaya (cultural contact) dengan budaya setempat yang masih hidup dan berkembang. ${ }^{4}$ Sungguhpun begitu model akulturasinya bukan untuk saling mengalahkan antar satu budaya dengan budaya yang lain, tetapi lebih pada pengembangan pola nalar keagamaan serta usaha mempertemukan jembatan yang memisahkan antara agama dan budaya. ${ }^{5}$ Inilah cikal bakal persediaan modal sosial yang terinternalisasi dalam struktur sosial masyarakat pesantren.

Berdasarkan perpaduan ajaran islam dan tradisi lokal tersebut, kharakteristik masyarakat pesantren: (1) kedudukan terpenting dalam tata

\footnotetext{
1 Achmad Maulani, Pembaruan Dan Peran Sosial Transformatif Pesantren Dan Islam Indonesia (Sosiologi Reflektif, Volume 10, N0. 2, April 2016) 159-184

2 Andi Purwono, "Organisasi Keagamaan Dan Keamanan Internasional: Beberapa Prinsip dan Praktik Diplomasi Nahdlatul Ulama (NU) Indonesia” (Jurnal Politik Profetik Vol 2 No 2, 2013)

${ }^{3}$ Hamdan Farchan \& Syaifuddin, Titik Tengkar Pesantren: Resolusi konflik pesantren (Yogyakarta: Pilar Religia 2005), 150

4 Achmad Maulani, Pembaruan dan Peran Sosial Transformatif Pesantren Dan Islam Indonesia, 169

5 Abdurrahman Wahid, Pesantren sebagai Subkultur. Pesantren dan Pembaharuan (LP3ES, Jakarta 1988) 39-60
} 
nilainya adalah pencapaian penerimaan disisi Allah ${ }^{6}$ (2) orientasi kuat terhadap kiai, yaitu traditional authority relationship yang tidak simetris antara kiai dan santri. Kiai beserta pembantu-pembantunya merupakan hierarki kekuasaan satu-satunya yang secara ekplisit diakui di lingkungan pesantren dan masyarakat di sekitar lokasi pesantren. ${ }^{7}$ Sub culture pesantren, guru dianggap sebagai penyalur barokah 8 (3) watak pribadi seperti kemandirian, kesederhanaan dan kesetiakawanan ${ }^{9}$ (4) jaringannya cukup solid ${ }^{10}$ (5) solidaritas yang tinggi antara sesama santri11 (6) pendukung utamanya terdapat di perdesaan dengan pengikut utama adalah kaum petani dan pedagang12 (7) toleransinya tinggi terhadap budaya Indonesia. ${ }^{13}$

Nilai-nilai Islam yang diyakini dan disebarkan melalui dakwah bil hal atau interaksi sosial diantara kalangan pesantren dalam jangka waktu ratusan tahun akhirnya terinternalisasi dalam budaya masyarakat Indonesia khususnya keluarga santri dan masyarakat di sekitar lokasi pesantren berada. Disinilah kekuatan luar biasa yang dimiliki oleh pesantren yaitu keterlekatan modal sosial dalam diri keluarga santri (santri, wali murid, ustad dan kerabat dekatnya) dan masyarakat sekitarnya. ${ }^{14}$ Di Indonesia, modal sosial yang dipengaruhi nilai-nilai keagamaan seperti pesantren dipandang lebih penting dan terintegrasi pada skala yang lebih luas terhadap beragam aspek dalam kehidupan masyarakat Indonesia. ${ }^{15}$

Sebagai penjelasan pembangunan tidak hanya terkait ekonomi an sich tetapi juga non-ekonomi dan kelembagaan yang melingkupi ekonomi. ${ }^{16}$ Salah

${ }^{6}$ Ibid, 42

${ }^{7}$ Muhamad Luqman, Pesantren Vis A Vis Tafsir Penguasa Menggagas Pesantren Masa Depan (Qirtas, Qalam Yogyakarta 2003)

8 Zamakhsyari, Dhofier, Tradisi Pesantren: Studi tentang Pandangan Hidup Kyai (LP3ES, Jakarta 1983), 82

9 M.M, Billah, Pikiran Awal Pengembangan Pesantren Pergulatan Dunia Pesantren Membangun dari Bawah. (P3M, Jakarta 1985) 291

10 Hamdan, Farchan, dan Syarifudin, Titik Tengkar Pesantren: Resolusi Konflik Masyarakat Pesantren, 67

${ }^{11}$ Abdurrahman Wahid, Pesantren sebagai Subkultur, 45

12 Dawam, M, Rahardjo, Dunia Pesantren dalam Peta Pembaharuan Pesantren dan Pembaharuan (LP3ES, Jakarta 1988), 1-6

13 Achmad Maulani, Pembaruan Dan Peran Sosial Transformatif Pesantren Dan Islam Indonesia, hlm. 161

14 Balitbangda Pamekasan, Kelembagaan Ekonomi Pesantren. (Balitbangda Pamekasan, 2008), 64

15 Risti Permani, "The presence of religious organisations, religious attendance and earnings: Evidence from Indonesia" (The Journal of Socio-Economics, 2011)

16 Ben Fine and Costas Lapavitsas. "Social Capital and Capitalist Economies," South Eastern Europe Journal of Economics.1. ASECU (2004): 23 
satu kajiannya dari gabungan ketiga bidang ilmu ini adalah teori modal sosial. Modal sosial berupa norma, kepercayaan dan jaringan ${ }^{17}$ atau meminjam istilah modal sosial mencakup tiga dimensi yang menjadi fokusnya yakni dimensi structural, relasional dan kognitif. Dimensi struktural mengacu pada pola keseluruhan hubungan antar individu, sementara relasional menekankan pada hubungan antar individu dalam rentang waktu yang lama dari generasi ke generasi sehingga terbentuk kesepakatankesepakatan bersama untuk kepentingan dan kebutuhan diantara mereka. Dimensi ini dalam bentuk norma (norm of reciprocity). Dimensi kognitif mengacu pada sumberdaya yang memungkinkan gambaran, penafsiran dan sistem bersama yang memiliki makna diantara pihak-pihak yang terlibat dan aspek kuncinya bisa berupa bahasa, budaya dan visi bersama. ${ }^{18}$

Modal sosial sebagian besar diwariskan dari generasi ke generasi. Ini menunjukkam bahwa dibutuhkan rentang waktu yang sangat lama melalui interaksi yang mengijinkan untuk membangun kepercayaan dan norma. ${ }^{19}$ Seperti bentuk modal (capital) yang lainnya (human capital, natural capital, finansial capital dan physical capital), modal sosial membutuhkan waktu dan energi untuk pembentukannya.

Bank Dunia menyatakan bahwa modal sosial sebagai alat yang memiliki peranan untuk mengurangi kemiskinan. ${ }^{20}$ sehingga Bank dunia mengadopsi dan mendorong ide modal sosial sebagai 'missing link' dalam menjelaskan pembangunan. ${ }^{21}$ Sederhananya, Hal yang diharapkan bahwa komunitas yang dianugerahi dengan persedian modal sosial yang tinggi menjadi lebih aman, lebih bersih, lebih sehat, lebih banyak yang bisa membaca, lebih baik dalan pengelolaan, dan umumnya lebih "bahagia" daripada mereka yang minim persedian modal sosialnya, karena umumnya komunitas tersebut dapat menemukan dan melaksanakan pekerjaan dengan lebih baik, mengutamakan kepentingan pelayanan publik, biaya yang dikeluarkan lebih kecil untuk pengawasan atas perilaku satu sama lain, penegakan kesepakatan kontrak

17 Dell, Champlin "Social Capital and the Privatization of Public Goods" International Journal of Social Economics Vol 26 No.10/11. MCB University Press (1999), 1304, lihat Amartya Sen, Development as Freedom. Anchor Books, a division of Random House, Inc. New York. 263

18 Nahapiet,J, S. Ghostal (1998), Lu, y, D.Yang, (2011) dalam H.H, Chang, C. Y. Hung, C.Y. Huang, K.H. Wong and Y. Tsai, "Social capital and transaction cost on co-creating ITvalue towards inter-organizational EMR exchange," International Journal of Medical Informatics ${ }_{\llcorner}$ (2016)

19 Dhesi, Autar, S., "Social Capital and Community Development". Community Development Journal. Vol 35 No. 3 July (2000) 202.

${ }^{20}$ World bank, 1998 in Joe, Wallis, Paul Killerby, and Brian Dollery," Social Economics and Social Capital," (2004) 239

${ }^{21}$ Ben Fine, and Costas Lapavitsas, Social Capital and Capitalist Economies: 21 
lebih mudah, penggunaan sumber yang ada lebih efisien, penyelesaian perselisihan lebih bersahabat, dan respon kesadaran warganya lebih cepat. ${ }^{22}$

Modal sosial tidak selalu berpengaruh positif. Manfaat yang dirasakan dengan persediaan modal sosial yang tinggi yakni sebagai sumber kontrol sosial, sebagai sumber dukungan keluarga, sebagai sumber manfaat melalui jaringan ekstra familial. ${ }^{23}$ Sumber daya yang terlekat dalam jaringan sosial dapat memfasilitasi akses terhadap informasi, ikatan sosial mempengaruhi memiliki peran kritis dalam pengambilan keputusan, sebagai sertifikat dari kepercayaan sosial individu dan memperkuat identitas dan pengakuan. ${ }^{24}$ Adapun konsekuensi negatif dari modal sosial yaitu menutup diri (exclusive) dari pihak luar, membatasi kebebasan individu, ${ }^{25}$ jaringan dan interaksi sosial dapat menyebabkan sifat yang cenderung melanggar hukum, menyuburkan korupsi, penyuapan, kejahatan, nepotisme, dan kroniisme. ${ }^{26}$

Tujuan tulisan ini untuk mendiskripsikan kelekatan modal sosial pesantren dalam kehidupan keluarga santri di Pulau Madura, karena Pulau Madura dikenal sebagai Pulau Seribu pesantren, keberadaannya mempengaruhi struktur dan interaksi sosial masyarakat di Pulau Madura, dimana didalamnya terlekat modal sosial. Modal ini bisa dimanfaatkan sebagai kekuatan besar untuk menjadikan pesantren berkontribusi nyata dalam persoalan kemanusiaan atau sebagai rahmatan lil'alamin bagi bangsa Indonesia khususnya keluarga santri.

\section{Metode}

Tulisan ini didasarkan pada hasil penelitian dengan menggunakan pendekatan kualitatif deskriptif. Data diperoleh dari sumber primer dan sekunder. Data primer dari hasil observasi personal dibeberapa titik lokasi di Pulau Madura yakni Kabupaten Pamekasan mencakup Kecamatan Palengaan, Pakong, Pamekasan dan Pasean; Kabupaten Sampang meliputi Kecamatan Sokobanah dan Ketapang serta Kecamatan Prenduan Kabupaten Sumenep. Data sekunder diperoleh dari hasil penelusuran pustaka.

22 Michael, Woolcock, Social Capital and Economic Development: Toward a Theoretical Synthesis and Policy Framework : 155

${ }^{23}$ Alejandro, Portes "Social Capital: Its Origin and Applications in Modern Sociology Annual Review Sociology," Vol. 24. (1998) : 15-17

${ }^{24}$ Nan Lin, "Social Capital: A Theory of Social Structure and Action," Cambridge University Press (2001) 19-20 $15-17$

25 Alejandro, Portes "Social Capital: Its Origin and Applications in Modern Sociology,"

26Paul, Streeten, "Reflection on Social and Antisocial Capital",(Edward Elgar Cheltenham, UK. Northampton, USA, 2002):44 


\section{Hasil dan Diskusi}

Pesantren tertua di Madura adalah Pesantren Darul Ulum Banyu Anyar yang didirikan tahun 1787 M. ${ }^{27}$ Tahun 2013 jumlah pesantren di wilayah ini sudah mencakup 1.094 dengan jumlah santri 230,769.28 Jika dibandingkan dengan total pesantren di Jawa Timur proporsinya $19.89 \%$ sementara proporsinya dengan total pesantren di Indonesia mencapai 4\%. ${ }^{29}$ Adapun data pesantren per Kabupaten di Pulau Madura dapat dilihat pada Tabel 1.

Tabel 1. Jumlah pesantren dan Santri per kabupaten di Pulau Madura Tahun 2013-2016. ${ }^{30}$

\begin{tabular}{|c|c|c|c|c|c|c|}
\hline \multirow{2}{*}{ District } & \multicolumn{2}{|c|}{ Jumlah pesantren } & \multicolumn{2}{|c|}{ Santri } & \multicolumn{2}{c|}{ Ustad } \\
\cline { 2 - 7 } & $\mathbf{2 0 1 3}$ & $\mathbf{2 0 1 6}$ & $\mathbf{2 0 1 3}$ & $\mathbf{2 0 1 7}$ & $\mathbf{2 0 1 3}$ & $\mathbf{2 0 1 6}$ \\
\hline Sumenep & 239 & 263 & 53.052 & 74.104 & 3.764 & 5.283 \\
\hline Pamekasan & 201 & 204 & 59.007 & 81.594 & & 5.455 \\
\hline Sampang & 418 & 351 & 52.182 & 54.168 & 1.243 & 2.881 \\
\hline Bangkalan & 236 & & 66.528 & & 3.841 & \\
\hline Total & 1.094 & 818 & 230.769 & 209.866 & 8.848 & 13.619 \\
\hline
\end{tabular}

Sumber : BPS Pamekasan,Sampang dan Sumenep

\section{Modal Sosial Yang Dimiliki Pesantren}

Al-Qur'an, sunnah dan hadits, ijma', qiyas dan ijtihad merupakan aturan formal sumber hukum Islam (syariah) yang menjadi rujukan Pesantren. ${ }^{31}$ Ahlusunnanah wal-jamaah dapat diartikan para pengikut tradisi Nabi Muhammmad dan ijma' ulama. ${ }^{32}$ Trilogi ahlus sunnah wa jamaah mencakup aspek Akidah, syariah dan tasawuf (akhlak). Ketiganya merupakan satu kesatuan ajaran yang mencakup seluruh aspek prinsip keagamaan Islam. ${ }^{33}$ Akidah didasarkan pada manhaj (pemikiran) Asy'ari-Maturidi.

27 LPI Darul Ulum. Panduan Santri. Darul Ulum. Pondok Pesantren. Banyuanyar. Pamekasan. Madura. Tidak dipublikasikan. 2003

28 Kemenag, 2013 , see BPS Pamekasan, Sampang, and Sumenep, http://ponpes.net/daftar-pondok-pesantren-di-bangkalan-madura; http://jatim.kemenag.go.id/file/file/data/xloq1395925488.pdf (2017)

29 Kemenag, "Statistik Pendidikan Diniyah dan Pesantren - Pendis Kemenag," pendis.kemenag.go.id/file/dokumen/bukusaku1102.pdf,P DPP,Grafik Pesantren Per Provinsihttp://pbsb.ditpdpontren.kemenag.go.id/pdpp/about. (2016)

30 BPS Pamekasan, Sampang, and Sumenep, http://ponpes.net/daftar-pondokpesantren-di-bangkalan-madura; http://jatim.kemenag.go.id/file/file/data/xloq1395925488.pdf (2017)

31 Mannan, Muhammad Abdul, "Ekonomi Islam: Teori dan Praktek," Potan Arif Harahap (translator). Intermasa, Jakarta. (1992)

32 Zamakhsyari Dhofier, Tradisi Pesantren: Studi tentang Pandangan Hidup Kyai, hlm. 148

33 PWNU, Jawa Timur. Aswaja An-Nahdliyah. hal.3 
Empat madzhab (jalan atau aliran) dalam bidang fikih yakni Mazhab Hanafi, Maliki, Syafi'i dan Hambali. Fiqih disini dimaknai sebagai ciri khas yang dimiliki oleh mujtahid, berupa produk-produk hukum furu'iyah yang bersifat ijtihadi dan digali dari dalil-dalil yang zhanni (bersifat asumtif). Dalam bidang tasawuf menganut manhaj Ali Zainal Abidin, Abu Yazid Al Bistami, Al-Harits al-Muhasibi, Junaid al-baghdadi, Imam al-Ghazali dan serta para imam yang lain yang sejalan dengan syariat Islam. ${ }^{34}$

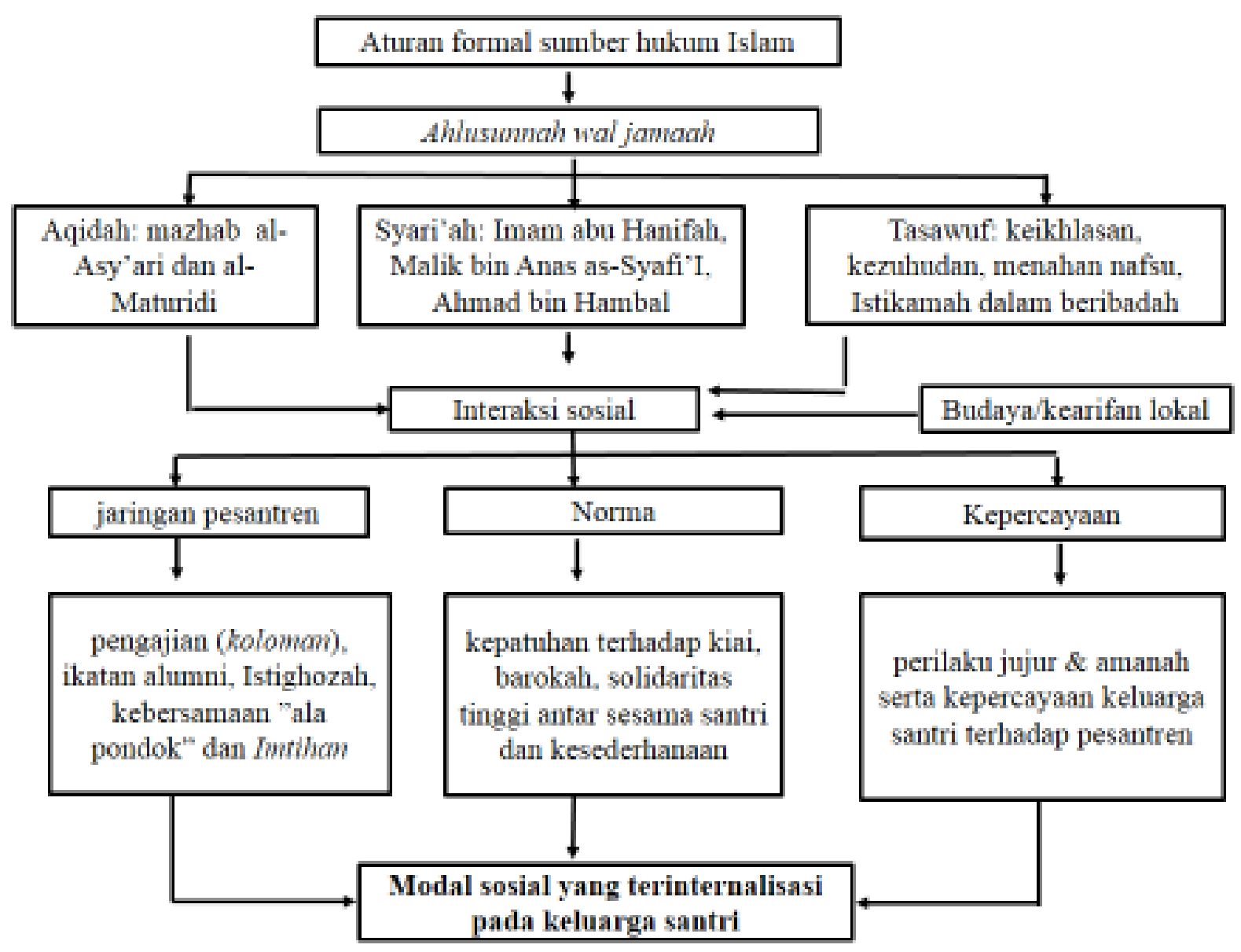

Gambar 1. Modal sosial yang terinternalisasi pada keluarga santri

(Diolah dari beragam sumber) ${ }^{35}$

34 A.Qusyairi Ismail., Achyat Ahmad., Ali Wafa., dan Ahmad Biyadi, "Trilogi Ahlusunnah: Akidah, Syariah dan Tasawuf," Pustaka Sidogiri PP Sidogiri (2012) 280-310.

35 Farahdilla Kutsiyah, "Analisis Kinerja....," P. Permani, The economic of Islamic... p. Sulthon, Aswaja An-Nahdliyah. p. 3 Zamakhsyari Dhofier, Tradisi Pesantren: .., p. 148, Abdurrahman Wahid, Pesantren sebagai Subkultur. p. 39-60, Zamakhsyari, Dhofier, Tradisi Pesantren... p. 82, M.M, Billah, Pikiran Awal Pengembangan.... p. 291, Hamdan, Farchan, dan Syarifudin, Titik Tengkar Pesantren... , p.67, Achmad Maulani, Pembaruan ..., p. 169, Dawam, M, Rahardjo, 1988 Dunia..., p. 1-6, A.Qusyairi Ismail., Achyat Ahmad., Ali Wafa., dan Ahmad Biyadi. Trilogi Ahlusunnah: Akidah, Syariah dan Tasawuf , 280-310 
Nilai-nilai pokok tasawuf adalah keikhlasan, kezuhudan, menahan nafsu, Istikamah dalam beribadah. Adapun pokok-pokok ajaran tasawuf adalah kebeningan hati dan muhasabah (mengoreksi diri), tujuannya hanya Allah, hidup zuhud dan selalu merasa butuh kepada Allah, memantapkan hati terhadap belas kasih dan cinta, dan terakhir yakni menghiasi diri dengan alkhlakul karimah. ${ }^{36}$

Seiring waktu jumlah santri semakin bertambah, pesantren kemudian berkembang menjadi sebuah komunitas keagamaan, dengan pola kehidupan yang mengedepankan norma, akhlak, moral dan ketaqwaan, sehingga pembelajaran dan sekaligus praktik-praktik keagamaan menjadi konsentrasi utama. ${ }^{37}$ Ini berarti ulama dan pesantren menjadi basis dari pembentukan kaum santri yang diwariskan dari karakter model pengajaran di pesantren yang dibangun dan dikembangkan para ulama. ${ }^{38}$

Karakter model pengajaran di pondok pesantren, pemahaman dan keilmuan Islam para kiai dengan sentuhan dengan budaya local masyarakat, lama kelamaan menjadi cikal bakal modal sosial para santri dan para alumni, wali santri serta masyarakat dimana pesantren tersebut berada. Dalam kurun waktu panjang dari generasi ke generasi telah menjadi modal sosial keluarga santri. Otentitisitas pesantren sebagai perwujudan wajah Islam Indonesia.

\section{Modal Sosial Keluarga Santri}

Otentitisitas pesantren sebagai perwujudan wajah Islam Indonesia, dalam kurun waktu panjang dari generasi ke generasi telah menjadi modal sosial keluarga santri. Adapun cakupan modal sosial terlekat pada keluarga santri yang meliputi norma, jaringan dan kepercayaan. Norma mencakup kepatuhan terhadap kiai, barokah, solidaritas tinggi antar sesama santri atau mudahnya disebut kesetiakawanan, dan kesederhanaan. Ikatan interaksi sosial sehingga terbentuk jaringan seperti pengajian rutin, isthighozah, Imtihan, ikatan alumni dan kebersamaan ala "pondokan". Kepercayaan dalam implementasi seperti perilaku jujur dan amanah, kepercayaan keluarga santri terhadap pesantren.

\section{a. Norma/Nilai}

Kepatuhan terhadap kiai terjadi dari proses panjang yang diawali minimal empat tahapan. Pertama, dakwah dan pendidikan yakni merubah

\footnotetext{
36 Ibid, hal 276-280

${ }^{37}$ Hasbullah, Moeflich, "Islam \& Transformasi Masyarakat Nusantara: Kajian Ssiologis Sejarah Indonesia,” Edisi kedua, Prenadamedia Group. Indonesia (2017) 90

38 Ibid, Hal: 109
} 
dan memperbaiki perilaku santri dan masyarakat sesuai dengan tuntunan agama Islam, baik melalui pendidikan formal maupun informal. Formal dalam kegiatan sentralistik di pesantren sementara informal melalui pengajian di masyarakat (wali santri), dimana masyarakat membuat kelompok pengajian yang dihadiri oleh kiai/ustad. Kedua, figure seorang kiai. Ciri yang terpatri dalam diri keluarga santri adalah tindak tanduk kiai yang selalu mengarah pada kebaikan. Ketiga, peran alumni cukup banyak memberi warna dari petuah kiai bahwa ilmu yang bermanfaat adalah ilmu yang disampaikan kepada orang lain. Dengan begitu proses mempengaruhi perilaku masyarakat persebarannya semakin luas. Keempat, tujuan hidup adalah kesempurnaan dan kedamaiaan disinilah pencapaian yang dirasakan oleh keluarga santri ketika menerapkan nilai-nilai dan norma pesantren. Kelima, Istilah "perjuangan atau jihad ala pesantren adalah para alumni berjuang mengamalkan ilmu yang telah dia peroleh selama menjadi santri.

Kepatuhan terhadap kiai didasari oleh, pertama, budaya patron dengan klien. Patron membantu para klien-kliennya. Para klien seringkali berusaha dapat memberikan arti moral kepada hubungan itu.Namun karena keterbatasan sumberdaya yang dimiliki posisi patron seringkali sangat lemah. ${ }^{39}$

Kiai seringkali hadir ketika keluarga santri atau masyarakat yang tinggal pesantren mengalami kesulitan ekonomi seperti memberi pinjaman modal, tidak perlu membayar uang mondok dan memberi kesempatan peluang kerja. Di samping itu, sebagai guru yang selalu mengarahkan pada kebaikan dan ketaqwaan serta mempererat tali silaturahmi dengan menghadiri pernikahan, acara selametan, atau meminimumkan konflik antar masyarakat (Tabel 2). Situasi ini memberi perasaan hutang budi, sehingga mereka berusaha dalam berbagai keadaan membalas kebaikan kiai, seperti sebagian besar petani yang juga merangkap sebagai orang tua santri mendatangi pesantren satu sampai tiga kali pertahun dengan membawa beras, uang, kayu atau hasil pertanian miliknya. Bentuk balas budi lainnya, mereka seringkali membantu pembangunan pondok pesantren/masjid.

39 James C Scott, "Moral Ekonomi Petani: Pergolakan dan Subsistensi di Asia Tenggara," Hasan Basri (translator). LP3ES, Jakarta (1981) 
Tabel 2. Hubungan antara Kiai sebagai patron dan keluarga Santri

\begin{tabular}{|l|l|l|}
\hline \multicolumn{1}{|c|}{$\begin{array}{c}\text { Bentuk dari rasa memiliki keluarga santri } \\
\text { terhadap pesantren berupa pemberian } \\
\text { materi dan tenaga }\end{array}$} & \multicolumn{1}{|c|}{ Bantuan dari Kiai } \\
\hline Beras & Pembangunan pondok pesantren & Sering membantu \& guru anak saya \\
\hline Kayu bakar & Pembangunan madrasah/pondok & Memberi ilmu dan bisa jadi panutan \\
\hline Uang, beras & Pembangunan pondok pesantren & Jika diundang selalu hadir \\
\hline Uang, beras & pembangunan pondok & $\begin{array}{l}\text { Selalu menolong masyarakat yang } \\
\text { mengalami kesulitan }\end{array}$ \\
\hline Uang, kayu & Pembangunan pondok pesantren & Sebagai guru \\
\hline $\begin{array}{l}\text { Mengabdi pada kiai, dengan merawat ternak } \\
\text { milik pesantren }\end{array}$ & $\begin{array}{l}\text { Dibiayai: sekolah, sandang-pangan, } \\
\text { perkawinan }\end{array}$ \\
\hline
\end{tabular}

\section{Sumber : data olahan}

Kedua, keyakinan terhadap barokah Kiai. Bertamu (sowan) mendatangi Kiai semata-mata untuk menperoleh barokah, mengabdi pada pesantren dan keluarga juga untuk mendapatkan barokah, pemberian sumbangan/infaq pada pesantren baik materi (uang, beras, kayu) dan tenaga untuk pembangunan masjid dan pondok pesantren juga untuk mendapatkan barokah. Bagi keluarga santri dan masyarakat disekitar pesantren selalu menyatakan bahwa dengan adanya pesantren akan memberi barokah bagi kehidupan mereka. Ungkapan yang sering diucapkan yakni tidak hormat dan tidak patuh terhadap Kiai akan membawa mudharat (celaka) dan kepatuhan akan membawa keberuntungan (barokah) dalam kehidupan seseorang. Ini menunjukkan bahwa persepsi baik apa pun tentang kiai akan membawa berkah dalam kehidupan seseorang, dan sebaliknya, sikap kurang ajar akan menyebabkan kualat. ${ }^{40}$

Ketiga, pola pendidikan pesantren memfokuskan pada wahana sosialisasi dan legitimasi mazhab, yang tidak lepas dari wacana ideologis tentang mainstream takzim (penghormatan, cenderung pengkultusan) terhadap Kiai sehingga berimbas pada proses transformasi ilmu maupun lainnya. Kitab Ta'limu al-Muta'alim merupakan pegangan di pesantren sebagai pedoman yang secara tidak resmi menjadi standar pola pendidikan pesantren. Kitab tersebut menjadi rujukan karena sistematika penulisan dan

\footnotetext{
${ }^{40}$ Nurcholish, Madjid, Bilik-Bilik Pesantren and Endang Turmudhi. Perselingkuhan Kiai dan Kekuasaan., 108
} 
isi materinya amat bagus. Hanya saja implementasi paparan buku ini acapkali lebih mengedepankan laku pengkultusan sang Kiai. ${ }^{41}$

Beberapa kutipan dari buku ta'limu al-muta'alim:

"sebagian dari memuliakan guru, ialah janganlah berjalan di depannya, jangan duduk di tempat duduknya, jangan memulai bicara kecuali mendapat izin darinya, tidak banyak bicara, dan janganlah mengajukan pertanyaan, jika guru sedang dalam keadaan tidak enak, dan jagalah waktu, jangan sampai mengetuk-ketuk pintunya. Tetapi sabarlah sebentar, tunggu sampai dia keluar. Ketahuilah, sesungguhnya orang yang mencari ilmu itu tidak akan memperoleh ilmu dan kemanfaatannya, kecuali dengan memuliakan ilmu beserta ahlinya, dan memuliakan guru. Aku tahu bahwa hak seorang guru itu harus diindahkan melebihi segala hak. Termasuk memuliakan guru, ialah menghormati dan memuliakan anak-anak serta famili-familinya." 42

Adapun pemahaman kitab ta'limu al-muta'alim dari corak santri adalah cara berbakti pada agama, sikap tunduk pada guru, bagaimana memilih teman dan guru, teknik memilih ilmu dan cara mencari rejeki serta syaratsyarat untuk memperoleh ilmu.

Keempat, keyakinan bahwa menjadi miskin dan tidak beruntung karena kurang iman. Hasil penelitian Horikoshi, menyebutkan ada keyakinan yang dipercayai bahwa menjadi miskin dan tidak beruntung adalah disebabkan kurangnya iman dan ketidakmahiran dalam aktivitas ekonomi serta agama membuat orang desa secara terus menerus berhutang dan merasa malu terhadap dirinya. Konsekuensi ekspresi antara ulama dan orang-orang desa nampak dalam hidup keseharian mereka. ${ }^{43}$

Norma yang paling mengemuka dalam lingkungan pesantren adalah memperoleh barokah. Hasil survei Kutsiyah terhadap 131 petani dengan proporsi $49 \%$ dari jumlah tersebut adalah keluarga santri, menjawab tata nilai dalam mempengaruhi harapan dan keputusan petani mengindikasikan harapan petani terhadap keberadaan pesantren proporsinya 83,8 \% untuk mendapatkan barokah. Disusul untuk mendapatkan ilmu. Kepatuhan terhadap kiai juga didasari untuk mendapatkan barokah yang mencapai 84,5

\footnotetext{
${ }^{41}$ Hamdan, Farchan, dan Syarifudin, "Titik Tengkar Pesantren: Resolusi Konflik Masyarakat Pesantren" 67

${ }^{42}$ Az Zarnuji, “Ta'lim Muta'allim Thariqat Ta'lim” Noor Aufa Shiddiq (Penerjemah). Al Hidayah, Surabaya (1999)

43 Hiroko Horikoshi, Kyai dan Perubahan Sosial. Thesis for the degree of Doctor of Philosohy in Antropology, University Illinois, USA. Umar Basalim dan Andi Muarly Sunrawa (Penerjemah). Perhimpunan Pengembangan Pesantren dan Masyarakat (P3M) Jakarta (1987)
} 
$\%{ }^{44}$ Ini menunjukkan bahwa setiap tindakan keluarga santri terkait dengan pesantren untuk memperoleh barokah. Karena bagi mereka barokah menjadi jalan meraih kesempurnaan hidup, keberkahan dan kehidupan yang diridhoi Allah swt, digampangkan memperoleh rejeki dan selalu merasa berkecukupan serta memudahkan terkabulnya doa. Ini berarti keyakinan terhadap barokah sangat kuat. Ketika ada dua pilihan yang ditawarkan antara materi dan barokah, maka mereka akan memilih memperoleh barokah daripada materi. Seorang peternak perempuan ketika ditanyakan alasan yang melatarbelakangi membantu pesantren yakni untuk memperoleh barokah. Sungguhpun begitu, dia tidak memungkiri, jika bisa mendapatkan keduanya (barokah dan materi) adalah lebih baik dan yang paling disukai.

Menurut bahasa, berkah berasal dari bahasa Arab: barokah, artinya nikmat.45 Istilah lain berkah dalam bahasa Arab adalah mubarak dan tabaruk.Menurut Kamus Besar Bahasa Indonesia, berkah adalah "karunia Tuhan yang mendatangkan kebaikan bagi kehidupan manusia". ${ }^{46}$ Menurut istilah, berkah (barokah) artinya ziyadatul khair, yakni "bertambahnya kebaikan". ${ }^{47}$

Pemahaman "makna barokah", bagi keluarga santri sangat beragam, bahkan yang terangkum dari beberapa narasumber, adanya pemahaman yang salah kaprah dari masyarakat dalam mengartikan barokah mengarah pada barokah kiai. Penafsiran barokah kiai diyakini seolah-olah atau seperti kemampuan luar biasa yang dimiliki kiai, yang memiliki makna positif dan negatif. Nurcholish Madjid mengemukakan, santri akan selalu memandang kiai dalam pengajian sebagai orang yang mutlak harus membawa keberuntungan (berkah/barokah) atau celaka (malati, mendatangkan mudharat). ${ }^{48}$

Barokah merupakan anugerah dari Allah swt, dimana manusia tidak mengetahui secara pasti. Dengan artian sebenarnya barokah merupakan "representasi atau refleksi kebaikan yang bersifat ilahi dan tidak diketahui sebelumnya kecuali oleh Allah". Dalam tataran ini sebetulnya kiai tidak bisa memberikan barokah karena barokah mutlak dari Allah SWT. Posisi kiai dalam hal ini hanya sebagai fasilitator untuk lebih mendekatkan diri kepada Tuhan. Artinya ketika santri sowan terhadap kiai, maka kiai akan

44 Farahdilla Kutsiyah. Analisis Modal Sosial dan Biaya Transaksi Pengembangan Agribisnis di Pesantren, Disertasi Universitas Brawijaya, (2008)

45 Ahmad Warson Al-Munawwir. Kamus Al-Munawwir, kamus bahasa Arab-Indonesia (1997) 78

46 Pusat Bahasa. Kamus Bahasa Indonesia. Departemen Pendidikan nasional (2008) 187

47 Imam Al-Ghazali, Ensiklopedia Tasawuf, p. 79

${ }^{48}$ Nurcholish, Madjid, Bilik-Bilik Pesantren, Paramadina, Jakarta (1997):23-24 
memberikan motivasi, mendoakan, memberikan arahan-arahan tentang cara bergaul dalam masyarakat dan pengetahuan.

Barokah merupakan representasi atau refleksi kebaikan yang bersifat ilahi yang tidak diketahui sebelumnya kecuali oleh Allah. Dan dari makna ini dapat dikembangkan secara luas pemaknaannya. Semua kebaikan, kebajikan. Barangkali makna barokah kiai yang dikatakan, kebaikan yang diperoleh masyarakat. Mungkin pemahaman dalam masyarakat, barokah kiai adalah kebaikan kiai. Merunut istilah Zamakhsyari Dhofier, kiai dianggap sebagai penyalur barokah. ${ }^{49}$

Masalah barokah sebenarnya telah mengakar dalam kebudayaan Islam Jawa. Kebiasaan-kebiasaan ini telah melahirkan sikap-sikap yang mungkin terlalu dilebih-lebihkan dan 'tidak diperbolehkan', menurut perspektif Islam. ${ }^{50}$ Karena seringkali kiai dianggap secara otomatis menjadi jimat dan jalan pintas yang diyakini masyarakat bahwa kiai bisa menentukan baikburuknya kehidupan mereka.

Senada yang dikemukakan oleh Nurcholish Madjid:

"santri akan selalu memandang kiai dalam pengajian sebagai orang yang mutlak harus membawa keberuntungan (berkah/barokah) atau celaka (malati, mendatangkan mudharat). Kecelakaan yang paling ditakuti oleh seorang santri dari kiainya adalah kalau sampai dia disumpahi sehingga ilmunya tidak bermanfaat. Karena itu santri berusaha untuk menunjukkan ketaatannya kepada kiai agar ilmunya bermanfaat, dan sejauh mungkin menghindarkan diri dari sikap-sikap yang bisa mengundang kutukan dari kiai tersebut. Dalam kesempatan menghadap kiai, misalnya karena minta izin hendak pulang atau pindah tempat, santri akan seringkali mendengar ucapan kiai" : 51

"Baiklah, dan saya do'akan engkau akan mendapatkan ilmu yang bermanfaat!". 52

Barokah biasanya terkait dengan karomah. Karomah adalah sifat yang dilekatkan kepada seorang yang dianggap suci karena ia dikatakan mampu memindahkan pertolongan Allah kepada orang yang membutuhkannya. Karena karomahnya, orang suci dapat melakukan hal-hal yang luar biasa. Dalam perspektif ortodoks tradisional, hijab telah menyembunyikan hal-hal ataupun makhluk gaib dari penglihatan manusia. Rahasia-rahasia Allah hanya diberikan kepada orang-orang tertentu yang dipilih, seperti para wali suci. Dengan kekuatan yang mereka terima dari Allah, para orang suci dapat

${ }^{49}$ Zamakhsyari Dhofier, Tradisi Pesantren: Studi tentang Pandangan Hidup Kyai, p. 84

${ }^{50}$ Endang Turmudhi "Perselingkuhan Kiai dan Kekuasaan," (Supriyanto Abdi (Penerjemah) LKiS. Yogyakarta., (2004) 108

${ }^{51}$ Nurcholish, Madjid, Bilik-Bilik Pesantren (Paramadina, Jakarta 1997):

52 Ibid,: 
melakukan hal-hal yang dalam pandangan manusia normal tidak biasa. Sehingga, permintaan oleh seorang kiai pada Allah, baik untuk dirinya sendiri maupun untuk orang lain, dapat lebih cepat dikabulkan. Mereka yang mempunyai karomah dapat memberikan barokah. ${ }^{53}$

Kesetikawanan menjadi bagian dari santri yang terbangun dalam interaksi intensif hidup bersama selama 24 jam perhari dan pertemanan bersama dalam kurun waktu lama kisaran tiga sampai sepuluh tahun. Mereka berucap "odik-odik bareng kancah". Selain itu ditopang nilai seperti mukmin bersaudara, saling membantu dalam kebajikan dan tidak membantu dalam perbuatan dosa dan permusuhan sesuai dengan hadist nabi bahwa muslim itu bagaikan saudara yang diandaikan satu tubuh, jika sakit satu maka yang lain ikut sakit. Dengan nilai-nilai yang ditanamkan sejak dini, maka nilai kesetiakawanan menjadi bagian dari diri para santri.

Solidaritas antar santri ini dalam bentuk saling membantu jika temannya mengalami kesusahan dan saling melengkapi agar tercipta kekompakan. Pertemanan yang erat ini akan berlanjut dan bahkan terkadang semakin kuat setelah menjadi alumni, biasanya masalah yang dihadapi salah satu alumni, maka mereka sebisa mungkin membantunya.

Kesederhanaan ditanamkan dalam diri santri sejak mereka masuk di pesantren agar kesehariannya benar-benar hanya diisi dengan ibadah dan menuntut ilmu. Dengan beragam latar belakang ekonomi mulai dari kaya hingga miskin dengan ditanamkan kesederhanaan maka kecemburuan sosial tidak terjadi dan juga tidak ada gap antara kaya dan miskin. Selain itu kesederhanaan akhirnya menjadi ciri santri karena ditunjang peraturan pondok pesantren dalam hal berpakaian dan kaitannya dengan konsumsi makanan. Dalam berpakaian seperti pembatasan jumlah baju yang dibawa dan harus memiliki seragam pesantren. Terkait dengan konsumsi, santri dituntut untuk memasak sendiri tidak boleh dikirim orang tua kecuali pada hari-hari tertentu sementara hal-hal lainnya mereka menggunakan fasilitas satu kamar berisi puluhan orang dan tanpa menggunakan kasur.

Kebiasaan yang mereka alami di pondok akhirnya membentuk perilaku santri ketika sudah lulus dan berkecimpung dengan masyarakat. Istilahnya jangan memaksakan diri, pengandaian seorang santri untuk menjelaskan tentang kesederhanaan

"kalau cukup makan dengan sayur dan tahu tempe, tetap merasa sudah cukup sehingga dengan begitu hidup orang tersebut tidak terfokus pada

${ }^{53}$ Endang Turmudhi. Perselingkuhan Kiai dan Kekuasaan. 
makanan. Sungguhpun begitu, ini bukan maksudnya menjustifikasi bahwa seorang muslim tidak boleh kaya, namun bagaimana meletakkan harta benda sebatas ditangan dan bukan di hati. Dengan sifat kesederhanaan maka sesorang menjadi Qona'ah dan selalu bersyukur, artinya tidak dikendalikan dunia tetapi kita yang mengendalikan. Qona'ah berarti merasa cukup dengan apa yang diberikan dan mensyukurinya agar disayang oleh Allah dalam kondisi apapun (Rahman dan Rahim Allah melekat pada diri kita)."

\section{b. Struktural: Jaringan}

Ikatan sosial atau keseluruhan pola hubungan antara kiai dengan santri, wali santri beserta kerabatnya. Semakin intensif kontak diantara mereka akan membantu memperkuat tingkat penyebaran informasi dan kerjasama. Beragam pola hubungan ini sehingga terbangun jaringan pesantren yang sangat solid secara rinci intensitas kontak ini dalam bentuk pengajian rutin/ tahlilan, istighozah, imtihan, ikatan alumni, kebersamaan ala pondugan. Jaringan pesantren juga terlihat pada saat pendistribusian bantuan, dan pemilihan umum.

Jalinan erat antara kiai dengan santri tanpak dalam kegiatan rutin baik harian, mingguan, bulanan ataupun tahunan. Ada tiga kegiatan rutin yang dilaksanakan di dalam lingkup pesantren. Pertama, pengajaran kitab kuning yang dilakukan oleh kiai melalui metode bandongan dan sorogan. Kedua, proses pendidikan formal mulai dari jenjang madrasah ibtidaiyah hingga aliyah atau sampai perguruan tinggi. Ketiga, musyawarah dan kegiatan ektrakurikuler di lingkup pesantren yakni seperti khitabah (lomba mengaji, pidato dll).

Pengajian rutin atau dikenal dengan sebutan tahlilan (Istilah di Madura disebut koloman) dilakukan oleh orang tua santri, dengan mengundang kiai atau ustad, biasanya pertemuan ini dilakukan pada saat bulan-bulan baik. Pengajian ini dapat dimaknai sebagai ajang silaturrahim untuk menjaga semangat keagamaan. Koloman adalah ciri khas ikatan komunitas lokal madura terutama yang tinggal di pedesaan. Koloman tersebut lebih banyak diisi dengan pengajian. Bentuknya seperti koloman hadrah, perkumpulan pentas seni hadrah dalam satu desa (seni musik dengan terbang alat khas perkusi yang diiringi dengan lagu-lagu puji-pujian pada Nabi Muhammad SAW dan tarian erka). ${ }^{54}$ Proporsi 61,07\% dari 131 responden masyarakat petani di Kecamatan Pamekasan yang kedudukannya baik sebagai wali murid, alumni ataupun bukan kedua-duanya mengikuti pengajian satu kali

54 Balitbangda Pamekasan. Studi sosial Ekonomi Kabupaten Pamekasan. (Balitbangda Pamekaan, 2002). 53 
hingga lebih dalam semingu, dan sisanya 39\% menghadiri pengajian antara satu kali atau dalam sebulan atau satu kali dalam dua-tiga bulan. ${ }^{55}$

Istighozah adalah sebuah bentuk permohonan kepada yang maha Kuasa untuk tujuan tertentu baik itu doa untuk memohon ampunan ataupun untuk memohon pertolongan agar memperoleh jalan keluar dari kesulitan yang dilakukan secara berjamaah. Biasanya istighozah dilakukan satu minggu sekali pada hari jum'at di pondok pesantren. Terkadang istighozah di luar pesantren dilakukan dengan tujuan mengharap agar hajat bisa tercapai baik dalam bentuk doa ketika terjadi musibah ataupun doa agar keinginan yang akan dilakukan bisa lancar. Seperti ketika ada peristiwa di Palestina maka pesantren mengadakan istighozah begitupula dengan pemilihan Bupati, Lora (putra Kiai) akan berangkat sekolah ke luar negeri ataupun Kiai yang akan membangun rumah.

Imtihan yaitu wisuda akhir tahun atau perayaan di akhir tahun yakni kenaikan kelas. Imtihan ini dilakukan satu hingga dua kali dalam setahun, tujuannya adalah mempererat silaturahmi antara wali santri dengan pesantren selain itu juga untuk mengetahui hasil belajar santri, karena pada acara ini akan dipilih santri terbaik yang mendapatkan apresiasi dari pesantren. Di samping itu pula sebagai bentuk ekpresi rasa syukur atas lulusnya santri. Imtihan ini biasanya berisi perlombaan baca kitab, debat tiga bahasa, sastra maupun olahraga yang berlangsung 7-14 hari, pada malam puncak dilakukan wisuda tajwid dan nahwu. Biasanya diselenggarakan ketika mendekati liburan pada bulan Ramadahan.

Sowan adalah santri atau wali santri /masyarakat menghadap kiai, ketika santri akan pulang maka akan sowan dulu atau masyarakat berkunjung ke pesantren untuk didoakan hajatan yang akan dilangsungkan agar berjalan lancar serta meminta saran untuk penentuan hari baik. Jaringan antara pesantren dengan alumni santri melalui keterikatan atau hubungan emosional antara kiai dengan seorang santri, sehingga ketika lulus keterikatan ini tetap selalu terhubung dalam frame silaturahmi baik dalam bentuk sowan, mengikuti istighozaah atau mengundang sang kiai ketika ada hajatan. Istilah mantan santri tidak dikenal, karena Dia telah menjadi santri, selamanya akan tetap menjadi santri. Ada suatu ungkapan bahwa sekali dia menjadi santri maka akan dibawa sampai akherat. Jaringan dengan para alumni didaerah tetap erat, meskipun sampai puluhan tahun.

Langgengnya jaringan dengan para alumni untuk menyambung silaturahmi dalam bentuk pengajian dan kerjasama lainnya. Kegiatan rutin

55 Farahdilla Kutsiyah, Analisis Kinerja Program BPLM Melalui Lembaga pesantren di Madura Kutsiyah 
seperti rapat umum pesantren dilaksanakan sebagai ajang pertemuan antara alumni, wali santri dan kiai. Di samping itu dibentuknya koordinator daerah yang merupakan kepanjangan tangan kiai dalam bidang pendidikan, ekonomi (pertanian, perdagangan), sosial (pengajian) dan politik (khususnya pada saat pemilihan umum). Tujuan kordinator daerah ini membantu menyelesaian persoalan di Masyarakat pedesaan, dan memfasilitasi kegiatan koloman di daerah (3) kunjungan masyarakat di sekitar pesantren atau wali santri yang dikehendaki secara bebas (4) haul atau Peringatan untuk mengenang wafatnya kyai, pada kegiatan ini akan hadir wali santri, dan pada saat itu juga dilakukan pengumpulan infaq.

Kebersamaan "ala pondugan". Santri yang mondok berarti dia harus tinggal di pondok. Perasaan kehilangan terasa ketika jauh dari keluarga pertama namun tidak selang beberapa lama dia akan mendapatkan keluarga baru. Keluarga pertama yakni teman satu kamar, biasanya satu kamar berisi 11 hingga 30 santri, disinilah kebersamaan hadir, karena saling membutuhkan mereka kemanapun saling menemani, dan yang paling cocok biasanya menjadi teman akrab. Bentuk kebersamaan ini dalam bentuk tidur bersama-sama, belajar bareng, makan bersama, sholat berjemaah bersama, begitupula dengan mengaji. Kebersamaan ini akhirnya membentuk ikatan solidiritas kuat diantara sesama santri. Istilahnya berada dalam ruang lingkup yang sama, kegiatan yang sama, peraturan yang sama dan dengan tujuan yang sama yaitu senasib seperjuangan menuntut ilmu, sukses dan mencari barokah. Keluarga kedua, yakni teman sekelas, karakter yang paling memiliki kesamaan akhirnya bersama-sama dalam grup pertemanan. Ketiga, dalam ruang lingkup yang lebih luas yakni linkungan pesantren mulai masjid, koperasi dan kegiatan lainnya.

\section{c. Kepercayaan}

Ketika sesorang memilih menjadi santri, maka ia wajib bertanggung jawab atas amanah yang diemban sebagai santri dan menjaga amanah dari kiai, seperti dalam bentuk mematuhi peraturan pondok ataupun bertanggung jawab terhadap tugas-tugasnya. Disinilah tahap awal kepercayaan tercipta antara santri dan kiai.

Etika dan moral dalam melakukan transaksi yang sesuai dengan syariah Islam adalah memiliki kharakteristik siddiq dan amanah, Siddiq artinya jujur baik dalam perkataan maupun perbuatan. Amanah dapat dipercaya, artinya sebagai indindividu tidak hanya menhindari dari perkataan bohongm akan tetapi juga dalam perbuatan dan kehidupan yang dijalani tidak hanya untuk diri sendiri tetapi juga u ntuk orang lain. 
Salah satu sifat Rasulullah, al-Shidqu, berarti jujur, benar, keterbukaan, tidak bohong, satunya hati-kata-perbuatan, oleh karena itu, dalam bermuamalah dan bertransaksi harus memegangi sifat al-Shidqu ini sehingga lawan dan kawan kerjanya tidak khawatir tertipu. Al amanah adalah dapat dipercaya memegang tanggung jawab dan memenuhi janji. ${ }^{56}$

Citra tersebut akan hadir dalam benak keluarga santri. Santri diajarkan untuk berperilaku jujur dan amanah baik perktaaan dan perbuatan, Dalam keseharian di pondok terutama pada program pendidikan ma'hadiyah santri dilatih dalam kesehariannya, begitupula terdapat pengawasan untuk tercapainya salah satu tujuan mendidik santri menjadi orang yang jujur dan amanah. Sifat ini melekat hingga keluar dari pondok pesantren, sehingga ketika mereka melakukan kerjasama terkait pertanian ataupun perdagangan dengan pesantren ataupun institusi lain, sangat menghindari berperilaku oportunis. Pengaruh dengan sifat tersebut akan mengurangi biaya transaksi khusnya terkait pengawasan dan kontrak. Merujuk Fukuyama bahwa kepercayaan, pada gilirannya merupakan produk dari komunitas-komunitas yang telah ada sebelumnya yang telah memiliki norma-norma atau nilai-nilai moral bersama. ${ }^{57}$

\section{Kesimpulan}

Paham ahlusunnah wal jama'aah adalah pegangan dunia pesantren. Ahlusunnah wal jama'aah mencakup tiga aspek akidah, syariah dan tasawuf (akhlak). Ketiganya merupakan satu kesatuan ajaran yang mencakup seluruh aspek prinsip keagamaan Islam. Pada saat penyebaran Islam, kearifan lokal diintegrasikan kedalam doktrin keagamaan dan budaya Islam. Akulturasi antara keduanya dalam rentang waktu yang panjang dari generasi ke generasi akhirnya terinternalisasi dalam struktur sosial keluarga santri dan masyarakat di sekitar lokasi pesantren berada.

Pulau Madura dikenal dengan pulau seribu pesantren. Keberadaan pesantren mengakar dalam kehidupan masyarakat Madura yang berada di pedesaan khususnya di lokasi pesantren berada. Inilah cikal bakal persediaan modal sosial yang melembaga dalam struktur sosial masyarakat pesantren di Pulau Madura.

\footnotetext{
56 PWNU, Jawa Timur. Aswaja An-Nahdliyah: 38

57 Francis Fukuyama, Trust: Kebijakan Sosial dan Penciptaan Kemakmuran, Penerjemah Ruslani. Qalam, (2002) 488
} 
Cakupan modal sosial terlekat pada keluarga santri meliputi norma, jaringan dan kepercayaan. Norma meliputi kepatuhan terhadap Kiai, barokah, solidaritas tinggi antar sesama santri atau mudahnya disebut kesetiakawanan, dan kesederhanaan. Ikatan interaksi sosial sehingga terbentuk jaringan seperti pengajian rutin (koloman), istighozah, Imtihan, ikatan alumni dan kebersamaan ala "pondokan". Kepercayaan yakni perilaku jujur \& amanah serta kepercayaan keluarga santri terhadap pesantren.

\section{Daftar Pustaka}

Ahmad Warson Al-Munawwir. Kamus Al-Munawwir, kamus bahasa ArabIndonesia, 1997.

Bakhri, Syaiful. M. Kebangkitan Ekonomi Syariah di Pesantren-Belajar dari Pengalaman Sidogiri. Cipta Pustaka Utama. Pasuruan, 2004.

Balitbangda Pamekasan. Kelembagaan Ekonomi Pesantren. Balitbangda Pamekasan, 2008.

Balitbangda Pamekasan. Studi sosial Ekonomi Kabupaten Pamekasan. Balitbangda Pamekasan, 2002.

Billah, M.M, Pikiran Awal Pengembangan Pesantren. Pergulatan Dunia Pesantren Membangun dari Bawah. Cetakan Pertama, Perhimpunan Pengembangan Pesantren dan Masyarakat (P3M) Jakarta, 1985.

BPS Pamekasan, Sampang, and Sumenep. http://ponpes.net/daftar-pondokpesantren;

http://jatim.kemenag.go.id/file/file/data/xloq1395925488.pdf , 2017.

Chang, H.H., C. Y. Hung, C.Y. Huang., K.H. Wong and Y. Tsai. "Social capital and transaction cost on co-creating ITvalue towards inter-organizational EMR exchange". International Journal of Medical Informatics. (2016)139.

Dhesi, Autar, S. "Social Capital and Community Development". Community Development Journal. Vol 35 No. 3 July. (2000): 199-214.

Dhofier, Zamakhsyari. Tradisi Pesantren: Studi tentang Pandangan Hidup Kyai. LP3ES. Jakarta, 1983.

Farchan, Hamdan., dan Syarifudin. Titik Tengkar Pesantren: Resolusi Konflik Masyarakat Pesantren. Pilar Religia, Kelompok Pilar Media, Yogyakarta, 2005.

Fine, Ben., and Costas Lapavitsas, "Social Capital and Capitalist Economies." ASECU South Eastern Europe Journal of Economics.1 (2004)17-34 
Fukuyama, Francis. Trust: Kebijakan Sosial dan Penciptaan Kemakmuran. Penerjemah Ruslani. Qalam, 2002.

Hasbullah, Moeflich. Islam \& Transformasi Masyarakat Nusantara: Kajian Ssiologis Sejarah Indonesia. Edisi kedua, Prenadamedia Group. Indonesia, 2017.

Horikoshi, Hiroko. Kyai dan Perubahan Sosial. Thesis for the degree of Doctor of Philosohy in Antropology, University Illinois, USA. Umar Basalim dan Andi Muarly Sunrawa (Penerjemah). Perhimpunan Pengembangan Pesantren dan Masyarakat (P3M) Jakarta. 1987

Ismail A.Qusyairi., Achyat Ahmad., Ali Wafa., dan Ahmad Biyadi. Trilogi Ahlusunnah: Akidah, Syariah dan Tasawuf. Pustaka Sidogiri PP Sidogiri, 2012.

PDPP, Statistik Pendidikan Diniyah dan Pesantren - Pendis Kemenag. pendis.kemenag.go.id/file/dokumen/bukusaku1102.pdf, 2016.

Kemenag. Grafik Pesantren Provinsi http://pbsb.ditpdpontren.kemenag.go.id/pdpp/about. 2018

Kutsiyah, Farahdilla. "Analisis Kinerja Program bantuan Pinjaman langsung Masyarakat Melalui Lembaga pesantren di Madura". Jurnal Agro Ekonomi (JAE) Vol 27 no. 2, (2009): 109-134.

Kutsiyah, Farahdilla. Analisis Modal Sosial dan Biaya Transaksi Pengembangan Agribisnis di Pesantren, Disertasi Universitas Brawijaya, 2008.

Lin, Nan. Social Capital: A Theory of Social Structure and Action. Cambridge University Press, 2001.

LPI Darul Ulum. Panduan Santri. Lembaga Pendidikan Islam Darul Ulum. Pondok Pesantren. Banyuanyar. Pamekasan. Madura. Tidak dipublikasikan, 2003.

Luqman, Muhamad. Pesantren Vis A Vis Tafsir Penguasa. Menggagas Pesantren Masa Depan. Qirtas, Qalam Yogyakarta, 2003.

Madjid, Nurcholish. Bilik-Bilik Pesantren. Paramadina. Jakarta, 1997.

Mannan, Muhammad Abdul. Ekonomi Islam: Teori dan Praktek. Potan Arif Harahap (Penerjemah). Intermasa, Jakarta, 1992.

Maulani, A. "Pembaruan dan Peran Sosial Transformatif Pesantren dan Islam Indonesia". Sosiologi Reflektif, Volume 10, N0. 2, April 2016: 159-184.

Permani, R. The economic of Islamic Education: Evidence from Indonesia. Thesis, University of Adelaide, 2009. 
Permani, R. "The presence of religious organisations, religious attendance and earnings: Evidence from Indonesia". The Journal of Socio-Economics 40 (2011) 247-258.

Portes, Alejandro. "Social Capital: Its Origin and Applications in Modern Sociology". Annual Review Sociology, Vol. 24. (1998) 1-24.

Purwono, A. "Organisasi Keagamaan Dan Keamanan Internasional: Beberapa Prinsip dan Praktik Diplomasi Nahdlatul Ulama (NU) Indonesia". Jurnal Politik Profetik. Volume 2 Nomor 2. (2013).

Pusat Bahasa. Kamus Bahasa Indonesia. Departemen Pendidikan nasional, 2008.

PWNU, Jawa Timur Aswaja An-Nahdliyah. Ajaran Ahlussunnah wa Al-jamaah yang Berlaku di Lingkungan Nahdlatul Ulama. Khalista Surabaya dan LTN NU Jawa Timur, 2006.

Rahardjo, Dawam, M. Dunia Pesantren dalam Peta Pembaharuan. Pesantren dan Pembaharuan. Cetakan Keempat, LP3ES, Jakarta, 1988.

Scott, James C. Moral Ekonomi Petani: Pergolakan dan Subsistensi di Asia Tenggara. Hasan Basri (Penerjemah). LP3ES, Jakarta, 1981.

Streeten, Paul. "Reflection on Social and Antisocial Capital. Social Capital and Economic Development: Well-being in Developing Countries". Edward Elgar. USA. (2002): 40-57.

Turmudi, Endang. Perselingkuhan Kiai dan Kekuasaan. Supriyanto Abdi (Penerjemah) LKiS. Yogyakarta, 2004.

Wahid, Abdurrahman, ed., Pesantren sebagai Subkultur. Pesantren dan Pembaharuan. Cetakan Ke empat, LP3ES, Jakarta, 1988.

Wallis, Joe., Paul Killerby., and Brian Dollery. "Social Economics and Social Capital. International Journal of Social Economics". Emerald Group Publishing Limited, 31(3), (2004): 239-578.

Woolcock, Michael. "Social Capital and Economic Development: Toward a Theoretical Synthesis and Policy Framework". Theory and Society. 27. Kluver Academic Publisher. Printed In The Netherlands. (1998): 151208.

Zarnuji, Az. Ta'lim Muta'allim Thariqat Ta'lim. Noor Aufa Shiddiq (Penerjemah). Al Hidayah, Surabaya, 1999. 